\title{
The Role of Textbooks to Support Scientific Approach Learning Implementation on Vocational High School (Book Review of Mechanics and Machine Elements for SMK Class X)
}

\author{
Riana Nurmalasari, Eddy Sutadji \\ Universitas Negeri Malang \\ Blima Oktaviastuti \\ Universitas Tribhuwana Tunggadewi \\ Sunardi \\ Universitas Negeri Gorontalo
}

E-mail address: riana.nurmalasari.ft@um.ac.id

\begin{abstract}
Textbooks are one of the supporting learning processes and must be prepared according to the applicable curriculum, namely the 2013 curriculum. In fact, not all books used in the learning process currently have quality content and relevant content suitability. Moreover, not all textbooks have been prepared using a scientific approach. One of the textbooks that needs to be reviewed is the Mechanics and Machine Elements for Class X on Vocational High Schools. There is a need for a study related to the suitability of the contents of the books according to KI and KD and adjust to aspects of the appropriateness of content, language, presentation, and graphic of textbooks. The preparation of the book must also adjusted to the scientific approach in accordance with the 2013's curriculum.
\end{abstract}

Keywords: textbooks, scientific approach, vocational high school

\section{INTRODUCTION}

Books have an important role in the development of science, because books are a source of learning (Prasad, 2016). Books can be categorized as practical learning resources given their flexible use, inexpensive maintenance and easy availability (Jhangiani, 2017). There are several types of books that can be prepared in learning (Fischer, 2017). One of these types of books is a textbook. Subject textbooks used in primary and secondary education units are selected from textbooks determined by the minister based on recommendations for eligibility assessment from the National Education Standards Agency (BSNP). There are required standards in the preparation of textbooks (Vorotnykova, 2019). In choosing a textbooks, an appropriate measurement standard is needed (Czegledy, 2008).

Textbooks serve as a source of teaching materials or learning tools for students as well as a guide for teachers (Vithana, 2015). In this case, the teacher has an important role in the learning process (Nurmalasari, 2016). One of its roles is to use the textbook function for learning process. In the classroom the teacher uses textbooks to ask questions to students to find out the level of student understanding (O.D Wonginsidi, 2019). The teacher must also accommodate student needs and student interest (Amiryousefi, 2011).

Textbooks are also complementary and even support the curriculum. At present, the curriculum used at vocational high school (SMK) is the 2013 curriculum using a scientific approach. Therefore, the preparation of textbooks must always support the scientific approach.

The reality shows that not all books have quality content and content conformity like core competence (KI) and basic competence (KD) in the curriculum. In addition, there are still many textbooks compiled that do not adjust the scientific approach that applies in the 2013 curriculum. As a result, the function of books as 
supporting learning is less than optimal. One example of a textbook whose contents and approach is not in line with the 2013 curriculum is the Mechanics and Machine Elements book for Class X on Vocational High School. In this book there are still a number of KI and KD that are not appropriate. In addition, this book is not suitable when applied to learning with a scientific approach.

\section{THE ESSENTIAL OF USING TEXTBOOK IN LEARNING PROCESS}

The use of the term textbook refers to curriculum and books centre (Puskurbuk) as a state institution authorized to determine all matters related to the book. Bacon (in Tarigan, 1986) states that textbooks are books that are designed, prepared, and compiled by experts in their fields and are equipped with appropriate teaching facilities for use in the classroom. In line with that, Arifin (2008) stated that textbooks are handbooks for a course written and compiled by experts in related fields and meet the principles of textbooks and are officially published and distributed. In more detail, Bacon (in Elmaghfirah. 2009) argues that textbooks are books designed for use in class, carefully arranged and prepared by experts in their fields and equipped with appropriate and harmonious teaching tools. Obrazovni (2009) states that textbooks are teaching tools that are prepared based on the curriculum.

The existence of textbooks is closely related to the learning process. This is consistent with the opinion of Cunningsworth (1993) which states that the existence of textbooks is to facilitate learning. The same thing was also stated by Kayapinar (2008) which states that textbooks are designed to help students in learning in class. Tomlinson (2006) states that textbooks are to help learners. Likewise, Kuzu's opinion (2007) states that textbooks are very important in the learning process. In line with this, Toms (2004) considers the importance of the meaning of a textbook to help students reflect on the learning that has been done. Based on some of the opinions above, it can be concluded that the textbook is a textbook containing subject matter, in accordance with the applicable curriculum, and can help students in learning. Munadi (2008) states that books are verbal learning media.
Gabrielatos (2004) states that textbooks cannot be used if they do not have pictures or illustrations. Sudjana (2007) said that from a number of Edmund Faison's research findings on the use of pictures, it was shown that to obtain maximum learning results. This is supported by Arsyad (2010) who concludes that visual stimulus results in better learning outcomes for tasks such as remembering, recognizing, recalling, and linking facts and concepts.

Furthermore, Dubin (1992) in his book wrote "effective writing demands that the language in either a commercial textbook or teacher-prerared materials embody basic sociolinguistic signposts by accurately indicating who says what to whom on what occasion and with what intent." , that in writing textbooks also must pay attention to many aspects, especially sociolinguistics. Tompkins (2006) states that good textbooks should be in accordance with students' knowledge and competencies.

Related to the making of textbooks, Arifin (2009) states that one of the benchmarks of a good textbook that is prepared in accordance with the learning plan. According to Alwasilah (1997) textbooks as teaching materials are used to achieve educational goals effectively and efficiently with all its components regulated. That is, there needs to be planning, agreement, and evaluation of each human component and its nonhuman components.

\section{ASSESSMENT OF TEXTBOOKS BY BNSP STANDARDS}

BNSP states that good textbooks have the appropriateness of content, language, presentation, and graphics at the educational level. This is in line with the Indonesian Minister of Education Regulation No. 45 of 2008 concerning the stipulation of 195 textbooks for vocational schools that the appropriateness of the content, language, presentation, and graphic textbooks were assessed by BNSP and determined by Ministerial Regulation.

Textbooks for each subject used in primary and secondary education units are selected from textbooks that have been determined by the Minister based on a feasibility assessment recommendation from the BSNP. Some components assessed included the appropriateness of content, language, presentation, and graphic 
textbooks. The standards for the appropriateness of the contents of textbooks include the suitability of the material with competency standards (SK) and basic competency (KD), the accuracy of the material, the updating of the material, encouraging curiosity, practicum and entrepreneurship, and enrichment. Furthermore, language eligibility standards include language suitability, communicative, dialogic and interactive, suitability with the development of students, compliance with Indonesian language rules, use of terms and symbols. In addition to the two things above, a good textbook must have a standard of presentation worthiness consisting of presentation techniques that are used well ordered, there are supporting the presentation, considering the meaningfulness and usefulness, using coherence and groove in the flow of thought.

\section{The role of mechanics and machine elements book for smk clas $x$ in scientific approach learning implementation}

The existing Book Mechanics and Machine Elements for SMK Class X consists of eight chapters which are mostly dominated by machine element material only. The mechanical aspects are not discussed in the book. The contents of the book are not in accordance with KI and KD in the 2013 curriculum, even though the book is designed for teaching materials in the 2013 curriculum. If examined deeper, almost $60 \%$ of the material in the book is in the form of tables which if students only see will not understand. In fact, in scientific approach learning, students are expected to be able to master $5 \mathrm{M}$ which consists of observing, asking, gathering information, reasoning, and communicating. If the contents of the book do not meet the eligibility criteria for content, readability, language, presentation, and graphic textbooks, it is not easy for students to use the book for independent learning without the assistance of the teacher.

Students find difficulties to ask if they are not confronted with interesting media. Interesting in this case is related to the presentation of the contents of the book itself. If the mechanical book which is in the form of numbers is only dominated by tables, it will tend to make students easily bored while studying the book. Teachers must be able to inspire students for want and able to ask questions. When teachers ask questions, the teacher must guide students to ask questions too.
When the teacher answers questions, the teacher encourages students to become good listeners. Teachers question are intended to obtain verbal responses.

The next activities is students need to try. Trying is a process of skill for develop knowledge in order to obtain authentic learning outcomes. The application of experimental or attempted method is intended to develop various domains of learning goals, namely attitudes, skills, and knowledge. The real learning activities for this are related to engineering mechanics and machine elements namely studying the theoretical basis of engineering mechanics, studying the functions of each machine element, recording phenomena that have been encountered in the field related to machine elements, analyzing, and presenting data, drawing conclusions on the results discussion, making reports and communicate the results of discussions or problem solving. All of these activities use a textbook source as one of the supports. So in this case, a good textbook must be able to deliver students in carrying out learning as intended in the scientific approach.

However, the expectation of using textbooks to maximize scientific approach learning is slightly hampered to be realized if the contents of the book are still as they are now. Where most books are only dominated by knowledge of machine elements and in the form of tables by ignoring the technical mechanics. Therefore, it is necessary to improve the quality of the Mechanics and Machine Elements for SMK Class $\mathrm{X}$ in order to realize textbooks that can indeed facilitate students in learning optimally.

\section{DEVELOPMENT of mechanics and machine elements book for smk clas $x$ USING scientific approach}

The 2013 curriculum use a scientific approach in implementing learning. Therefore, teaching materials such as textbooks should be prepared with substance that is in line with existing learning approaches. However, in reality, one textbook such as the Mechanics and Machine Elements for SMK Class X, after a more in-depth study, has not been able to support the scientific approach that has been applied in SMK.

Based on these conditions, it should be compiled a book Mechanics and Machine Elements for SMK Class $\mathrm{X}$ by considering a 
scientific approach as applied in SMK. The preparation of books using a scientific approach should adjust to the $5 \mathrm{M}$ in the 2013 curriculum. From the aspect of observing, the book should have made students interested in seeing and reading books in order to obtain new information. Aspects of asking, the presentation in the book should be able to stimulate students to think critically and then ask questions about what is not understood after reading the book. Next aspect of trying, the book is able to lead students to try independently to learn and solve the problems presented. Aspects of associating / reasoning, with the book students are encouraged to think critically in solving a problem. The final aspect of communicating, the book makes it easy for students to draw conclusions from what has been learned for later by students delivered the results of their understanding.

Book preparation by considering and using a scientific approach is expected to produce books that contribute more when implementing learning. Some things that need to be considered in relation to the Mechanics and Machine Elements for SMK Class X after further study are books should be written and compiled taking into account the curriculum, content eligibility, readability, linguistic abilities, as well as aspects in the preparation of books based on BSNP; books are compiled and developed using a scientific approach; the book is reviewed and refined especially on the suitability of the content with the current curriculum, the 2013 curriculum; machine element material is integrated with technical mechanics material so that it becomes a unity that is mutually supportive and sustainable; proportion of material adapted to $\mathrm{KI}$ and $\mathrm{KD}$; book writing should not only copy paste from the previous edition of the book; textbooks should be able to attract the attention of students; before a book is used as a support for learning it is better if it is examined first the feasibility of using a book; critical and reliable book reviewers are needed so that the books produced are good; book writing must be based on the delivery of knowledge as a whole, not just based on "project".

\section{CONCLUSION}

Based on the results of the study it can be concluded that the textbooks play an important role in the learning process. However, there are still concepts in the textbook that are not quite right so that it can cause misconceptions on students. Therefore, the teacher must be clever in choosing books that meet the textbook criteria. A textbook is said to be good if it is arranged based on the applicable curriculum and adjust to aspects of the preparation of books based on BNSP.

\section{REFERENCES}

Amiryousefi, Mohammad \& Ketabi, Saeed. 2011. AntiTextbook Arguments Revisited: a Case Study from Iran. Procedia Social and Behavioral Science. 15. p 215-220.

Alwasilah, A.Chaedar. 1997. Politics of Language and Education. Bandung: PT Remaja Rosdakarya.

Arifin, Syamsul and Kusrianto, Adi. 2008. Success in Writing Textbooks and Reference. Jakarta: PT Grasindo.

Arifin, Zainal. 2009. Learning Evaluation. Bandung: Remaja Rosdakarya.

Arsyad, A. 2010. Learning Media. Jakarta : Raja Grafindo Persada.

Cunningsworth, Alan. 1993. Choosing Your Coursebook. Oxford: Heinemann.

Czegledy, Istvan \& Kovacs, Andras. 2008. How to Choose a Teextbook on Mathematic. Acta Didactica Napocensia. 1(2): p 16-30.

Dubin, Fraida dan Elite Olshtain. 1992. Course Design. USA: Cambridge University Press.

Fischer, Lane; Ernst, David; Mason, Stacie. 2017. Rating theQuality of Open Textbooks: How Reviewer and Text Characteristics Predict Ratings. International Review of Research in Open and Distributed Learning. 18(4): p 142154.

Gabrielatos, Costas. 2004. IATEFL Teacher Trainers and Educators SIG Newsletter. Session Plan: The Coursebook as a Flexible Tool. 1(1): 2831.

Hu Yan, Hidenori Okuzaki, 2009.Synyh.Met.159 2225-2228.

Jhangiani, Rajiv \& Jhangiani, Surita. 2017. Investigating the Perceptions, Use, and Impact of Open Textbooks: A Survey of PostSecondary Students in British Columbia. International Review of research in Open and Distributed Learning. 18(4): p 172-192.

J.Y. Kim, J.H. Jung, D.E. Lee, J. Joo, 2002. Synyh. Met.126 311-316. 
Kayapinar, Ulas. 2008. Coursebook Evaluation by English Teachers. INONU University Journal of the Faculty of Education, 10 (1): 69-78.

Kuzu, Abdullah, Yavuz Akbulut, Mehmet Can Şahin. 2007. Application of Multimedia Design Principles to Visuals Used Incourse-Books: an Evaluation. Tool The Turkish Online Journal of Educational Technology-TOJET. 6(2): Article 1.

Prasad, Deepak; Totaram, Rajneel; Usagawa, Tsuyoshi. 2016. Development of Open Textbooks Learning Analytics System. International Review of Research in Open and Distributed Learning. 17(5): p 215-234.

Munadi, Yudhi. 2008. Learning Media: A New Approach. Jakarta: Gaung Persada Press.

Nurmalasari, Riana; Puspitasari, Poppy; Mardji; Hartiningtyas, Lativa; Suswanto, Hary. 2016. The Role of Sarjana Mengajar's Teachers for Student's Outcomes on Vocational High School. AIP Conference Proceeding. 1778. $\mathrm{p}$ $1-3$.

O.D, Wonginsidi. 2019. Questions and Instructions Found in Reading Sections Used in "Interlanguage: English for Senior High School Students XI" Textbook. Journal Kata Kita. 7(1): p 71-78.

S.K.M. Jönsson, J. Birgerson, X. Crispin, G. Greczynski, W. Osikowicz, A.W. Denier van der Gon, W.R. Salaneck, M. Fahlman, 2003.Synyh. Met. 139 1-10.

Sudjana, Nana et al. 2007. Teaching Media. Bandung: Sinar Bayu Algensindo Offset.
S. Timpanaro, M. Kemerink, F.J. Touwslager, M.M. De Kok, S. Schrader, Chem, 2004. Phys. Lett. 394 339-343.

Sungeun Park, Sung Ju Tark, Donghwan Kim, Curr. , 2011.Appl. Phys. 11 1299-1301.

Tarigan, Henry Guntur and Tarigan, Djago. 1986. Study of Indonesian Textbooks. Bandung: Angkasa.

Tomlinson, Brian. 2006. Connecting the Course Book. Retrieved from http://www.tesol.org/s tessol/index.asp.

Tompkins, Catherine J.; Rosen, Anital L.; Larkin, Heather. 2006. An Analysis of Social Work Teksbooks for Aging Content: how well do social work foundation tekss prepare students for our aging society?. Journal of Social Work Education. p 1-6.

Toms, Colin. 2004. General English Coursebooks and Their Place in an ESAP Programme. Asian EFL Journal. 6(1): Article 9.

Vorotnykova, Iryna. 2019. Organizational, Psychological, and Pedagogical Conditions for the Use of E-Books and E-Textbooks at School. Turkish Online Journal of Distance Education. 20(3): p 89-102.

Vithana, D.P.C. 2015. A Study on the Usage of Electronic Books of Undergraduates of Uva Wellasa University of Sri Lanka. Journal of the University Librarians' Association of Sri Lanka. 19(1): p 71-91.

Y. Wang, J. Phys, 2009.Conf. Ser. 152012023.

Yijie Xia, Kuan Sun, and Jianyong Ouyang,2012. $A d v$. Mater. 24 2436-2440. 